\title{
Sistem Monitoring dan Kendali Operasi Pompa Air di Daerah Persawahan
}

\author{
Agus Yoga Pratama, Bambang Hari Purwoto \\ Teknik Elektro \\ UMS \\ Surakarta, Indonesia \\ Yo94.tama@gmail.com \\ bhp179@ums.ac.id
}

\begin{abstract}
Abstraksi - Sistem irigasi di daerah persawahan terkadang tidak memenuhi kebutuhan air di daerah persawahan sehingga dibutuhkan sumber air yang lain. Sumber air lain yaitu dengan membuat sumur di daerah persawahan, maka dari itu dibutuhkan pompa air untuk memindahkan air dari sumur ke sawah. Terjangkaunya tenaga listrik di setiap daerah menjadikan banyak petani memanfaatkan listrik sebagai sumber tenaga dari pompa air. Proses pengairan yang lama dan waktu yang tidak menentu serta tidak efektif jika petani terus menunggui proses pengairan sawah. Selain itu, pompa air akan mengalami kerusakan apabila bekerja pada kondisi tanpa air atau beban berat seperti air lumpur secara terus menerus. Oleh karena itu, dibutuhkan alat untuk mengendalikan pompa air secara jarak jauh dan memonitoring kondisi pompa air jika pompa air bermasalah. Pompa air dikendalikan melalui SMS dengan mengirimkan perintah yang berguna menyalakan ataupun mematikan pompa air. Teknologi yang digunakan dalam hal ini adalah modul Global System for Mobile Communications, atau disingkat dengan GSM. Selain itu, digunakan pula sensor arus dan sensor water level. Sensor arus berguna memonitoring kondisi pompa air jika pompa air bermasalah atau rusak. Apabila pompa air bermasalah atau rusak, maka arus yang mengalir lebih besar $0.3 \mathrm{~A}$ sehingga menyebabkan boros tenaga listrik dan pompa dimatikan. Sensor water level untuk mendeteksi kondisi air dalam tanah apakah bekerja dengan baik ketika air tidak ada, maka pompa air dimatikan. Setiap proses yang telah dijalankan akan dikirimkan notifikasi SMS ke ponsel petani berupa pesan yang menandakan kondisi pompa.
\end{abstract}

Katakunci - Pompa Air, Modul GSM, SMS, Sensor Arus

\section{PENDAhUluan}

Saat musim kemarau, sistem irigasi di daerah persawahan sering kali tidak dapat memenuhi kebutuhan air untuk mengairi sawah. Untuk itu, diperlukan sumber air yang lain untuk memenuhi kebutuhan air tersebut. Di beberapa daerah, seringkali petani membuat sumur untuk mendapatkan air yang diperlukan untuk mengairi sawah. Dengan demikian diperlukan pompa air untuk menyalurkan air dari sumur ke sawah. Ketersediaan energi listrik yang sudah menjangkau hampir diseluruh daerah di indonesia, maka sebagian petani memanfaatkan tenaga listrik tersebut sebagai sumber tenaga untuk pompa air di persawahan.

Pengoperasian pompa air dimusim kemarau sangat rutin, serta sering skali diperlukan untuk mengaktifkan pompa air tersebut dalam jangka waktu yang lama. Sehingga menjadi tidak efektif apabila petani harus menunggui operasi dari pompa air tersebut. Selain itu, pompa air dapat mengalami kerusakan dan boros tenaga listrik apabila terus bekerja ketika mengalami beban berat dan tidak terdapat air. Dengan demikian diperlukan sistem kontrol jarak jauh yang bisa memonitor kondisi pompa air sekaligus mengendalikan kerja pompa air tersebut.

Penulis dalam pemecahan masalah tersebut membuat sebuat alat yang dapat memonitor kondisi dari pompa air melalui arus yang dibutuhkan ketika beroperasi dan ketersedian air di dalam tanah. Pompa air juga dapat dikendalikan apabila petani ingin menyalakan Pada dan mematikan pompa air. Dimana monitor dan kendali dari pompa air dapat dilakukan secara jarak jauh menggunakan ponsel melalui SMS.

Sistem kerja dari alat yang dibuat, menggunakan mikrokontroler yang berguna melakukan perintah dan proses pengolahan data. Alat akan di atur sesuai arus ketika pompa air beroperasi secara normal. Jika pompa air bekerja diatas arus normalnya maka pompa air akan dinonaktifkan dan sms akan dikirim ke petani bahwa pompa bermasalah dan dinonaktifkan. Begitu pula saat kondisi air didalam tanah tidak memenuhi kebutuhan. Sehingga kerusakan pada pompa air dapat dihindarkan. Alat yang dibuat akan melalukan proses sesuai dengan SMS yang dikirim pengguna dan memberikan balasan SMS apabila proses telah dilakukan.

\section{METODE}

Rancangan alat yang dibuat adalah sistem monitoring dan kendali pompa air dipersawahan. Pompa air dapat mengalami kerusakan bila bekerja terus menerus pada beban berat maupun ketika air kering. Selain itu, waktu yang cukup lama dalam melakukan pengairan area persawahan tidak efektif bila petani terus menunggui pompa air tersebut. 
Dalam perancangan alat ini diperlukan beberapa komponen yaitu sensor arus ACS712 yang digunakan untuk mendeteksi aliran arus ke pompa air. Sensor level air yang digunkan untuk mendeteksi level air. Modul gsm sim8001 yang digunakan sebagai komunikasi melalui sms dengan mikrokontroler. Relay sebagai saklar aliran listrik ke pompa air serta LCD 16x2 sebagai penampil hasil dari sensor. Mikrokontroler untuk alat yang dibuat menggunakan Arduino Uno R3. Setelah komponen tersedia kemudian melakukan tahap perancangan, yaitu perancangan perangkat keras dan perancangan perangkat lunak.

Perancangan perangkat keras yaitu melakukan penyusunan komponen terhadap mikrokontroler sehingga alat dapat berjalan sebagaiman mestinya. Berikut adalah gambar 1 diagram blok alat, gambar 2 rangkaian wiring perangkat keras, dan gambar 3 penempatan alat.

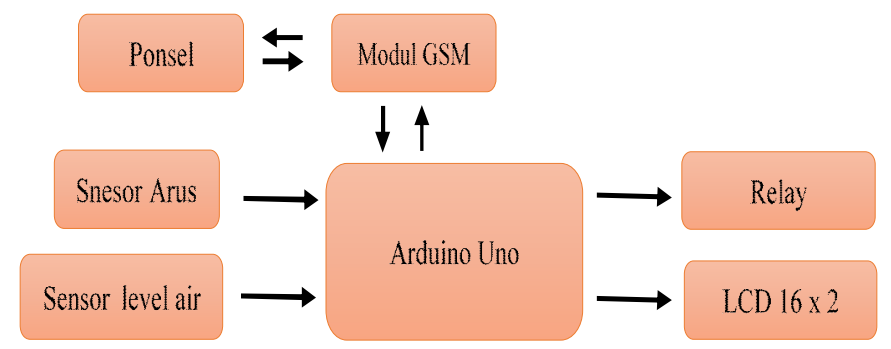

Gambar 1. Diagram Blofk Rangkain Perangkat Keras

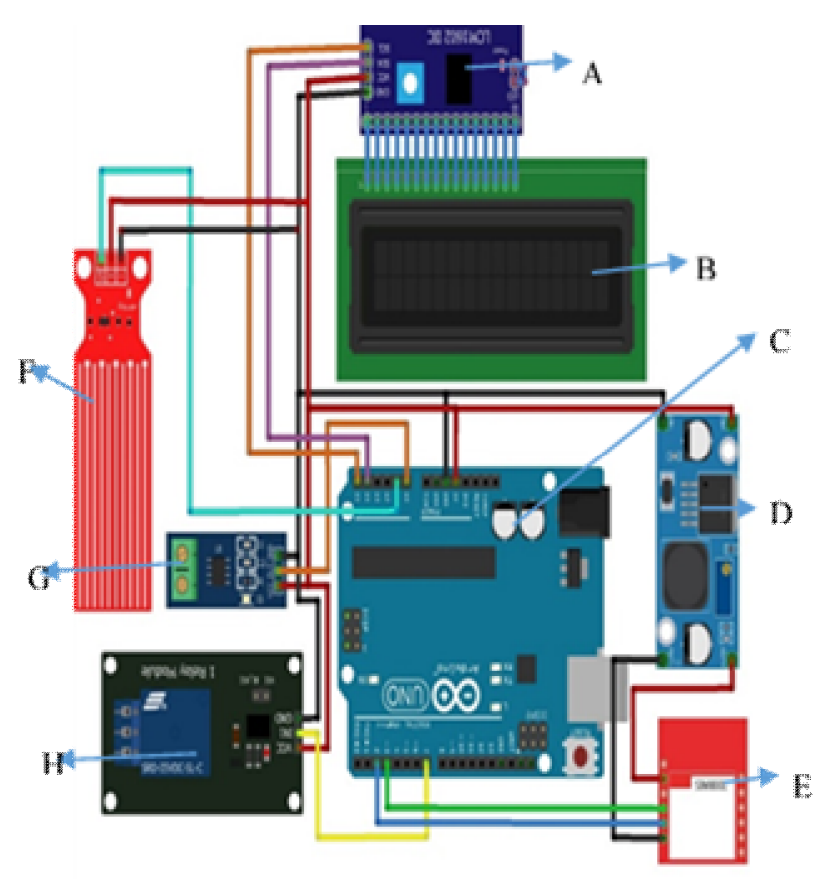

Gambar 2. Wiring Rangkaian Perangkat Keras
Keterangan:
A. $\mathrm{I} 2 \mathrm{C}$ LCD
E. Modul GSM SIM800L
B. LCD $16 \times 2$
F. Sensor Water Level
C. Arduino Uno R3
G. ACS712
D. Step Down Converter
H. Relay

DC-DC

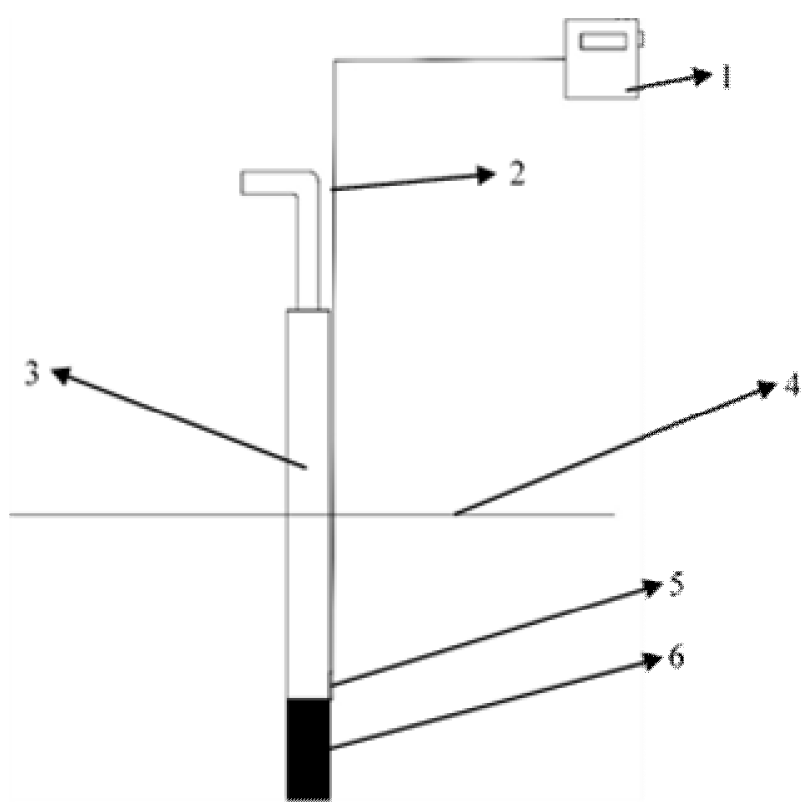

Gambar 3. Penempatan Alat

Keterangan:
1. Alat
4. Permukaan Air
2. Kabel Instalasi
5. Sensor Air
3. Pipa
6. Pompa Air

Perancangan perangkat lunak yaitu prinsip kerja dari mikrokontroler dari alat yang dibuat. Gambar 4 menunjukkan flowchart dari perancangan perangkat lunak. 


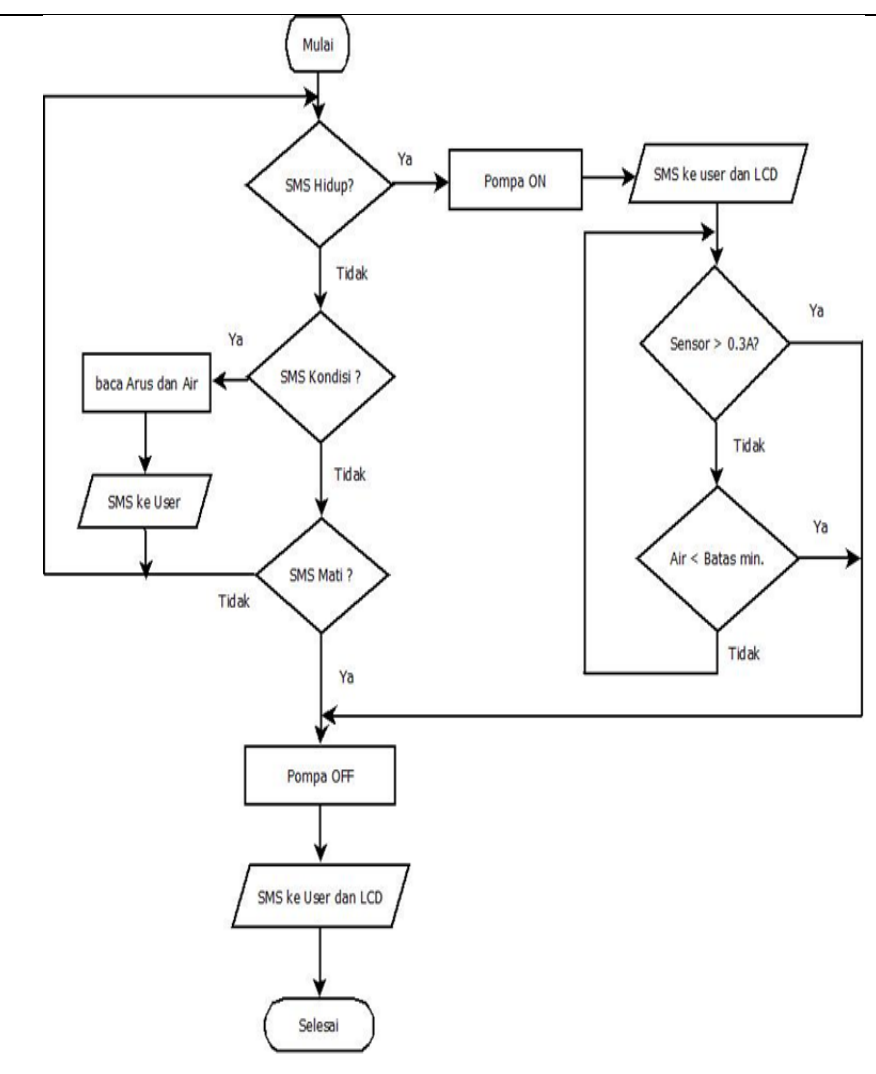

Gambar 4. Flowchart Cara Kerja Sistem

Alat yang dirancang akan bekerja dengan 3 perintah SMS. Ketika SMS "Hidup" dikirim pompa akan dihidupkan, setelah hidup alat mengirim SMS ke user. Selama pompa hidup apabila terdapat kondisi arus lebih besar 0.3A maka pompa dimatikan dan SMS akan dikirim ke user. Jika arus lebih kecil sama dengan $0.3 \mathrm{~A}$ pompa tetap hidup dan dilanjutkan dengan membaca kondisi air. Jika air di bawah batas minimum, maka pompa dimatikan dan SMS dikirim ke pengguna, sedangkan jika air diatas batas minimum pompa tetap hidup. Ketika alat menerima SMS, maka "Kondisi" alat akan membaca kondisi air dan arus, kemudian hasil pembacaan dikirim ke pengguna. Apabila SMS yang dikirim "Mati" maka Pompa dimatikan dan SMS akan dikirim olet alat ke pengguna. Bab II biasanya memuat penjelasan tentang metode yang digunakan dalam penelitian seperti alat dan bahan, rincian prosedur, algoritma atau langkah-langkah yang digunakan dalam pelaksanaan penelitian.

\section{HASIL DAN PEMBAHASAN}

\section{A. Desain Alat Yang Dihasilkan}

Alat yang dihasilakan terdiri dari LCD 16×2 sebagai penampil data alat, Sensor level Air berguna mendeteksi keberadaan air, Sensor Arus ACS712 untuk mendeteksi arus yang mengalir, Step Down Converter DC-DC untuk merubah tegangan $5 \mathrm{~V}$ menjadi $4 \mathrm{~V}$ ke Modul GSM SIM800L, Relay berfungsi sebagai saklar otomatis pompa, Arduino UNO R3 sebagai mikrokontroler yang memproses dan melakukan perintah dari sistem, Modul GSM SIM800L sebagai komunikasi melalui SMS, dan terdapat Push Button sebagi saklar manual dari alat. Gambar 5 memperlihatkan alat yang dihasilkan.

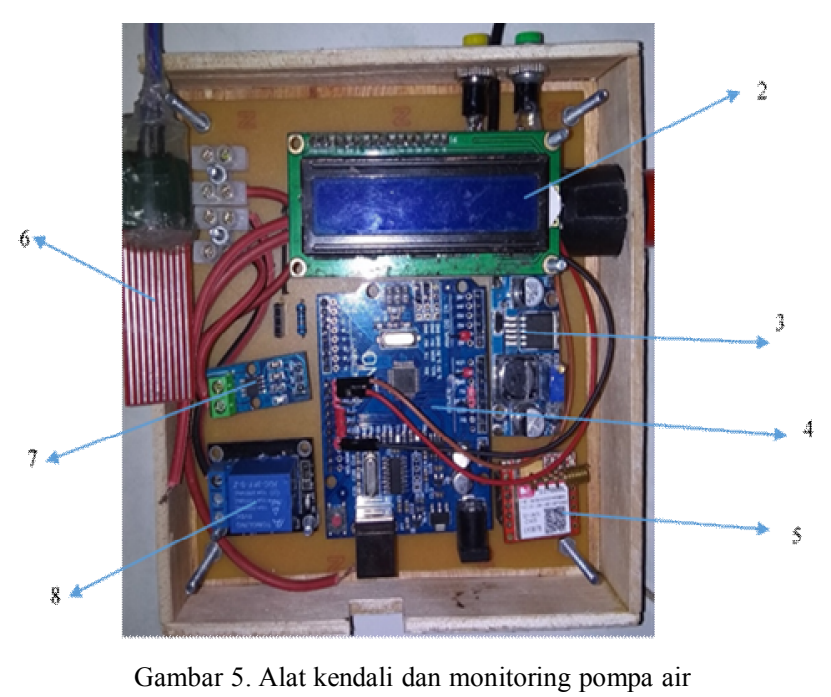

Keterangan:
1. Push Button
5. Modul GSM SIM800L
2. LCD $16 \times 2$
6. Sensor Water Level
3. Step Down Converter DC DC
7. ACS712
4. Arduino Uno R3
8. Relay

\section{B. Pengujian Sensor Arus ACS712}

Sensor arus yang digunakan adalah ACS712, dimana ACS712 bekerja dengan cara aliran arus yang masuk melalui tembaga di dalamnya menghasilkan medan magnet dan di tangkap oleh intergreted Hall IC dan diubah menjadi tegangan proposional. Sensor ACS bekerja baik. Namun, hasil pengukuran dari sensor harus dibandingkan dengan alat ukur yang lebih akurat yaitu multimeter digital. Tabel 1 menunjukkan hasil perbandingan pengukuran antara ACS712 dengan multimeter digital.

Tabel 1. Pengukuran Sensor Arus ACS712

\begin{tabular}{|c|l|l|l|l|}
\hline No. & $\begin{array}{l}\text { Penempatan } \\
\text { Pompa Air }\end{array}$ & $\begin{array}{l}\text { Pengukuran } \\
\text { ACS712 }\end{array}$ & $\begin{array}{l}\text { Pengukuran } \\
\text { Multimeter }\end{array}$ & $\begin{array}{l}\text { Selisih } \\
\text { Pengukuran }\end{array}$ \\
\hline $\mathbf{1}$ & Tanpa Air & $0.38 \mathrm{~A}$ & $0.39 \mathrm{~A}$ & $0.01 \mathrm{~A}$ \\
\hline $\mathbf{2}$ & Air & $0.22 \mathrm{~A}$ & $0.23 \mathrm{~A}$ & $0.01 \mathrm{~A}$ \\
\hline $\mathbf{3}$ & Air Lumpur & $0.31 \mathrm{~A}$ & $0.32 \mathrm{~A}$ & $0.01 \mathrm{~A}$ \\
\hline
\end{tabular}


Hasil pengukuran diatas adalah hasil uji sensor terhadap pompa kolam Yamano WP 105 yang ditampilkan di LCD $16 \mathrm{x}$ 2. Hasil uji coba menunjukkan nilai arus pompa air ketika menyala pada penempatan yang berbeda. Arus mengalami perubahan yang menandakan sensor arus bekerja dengan baik.

Hasil dari pengukuran arus digunakan untuk mengendalikan pompa Yamano WP 105 saat dihidupkan. Hasil pengukuran menunjukkan 0.22A ketika pompa air dihidupkan dalam air yang menandakan pompa air bekerja dalam kondisi baik. Arus 0.38 A ketika pompa dihidupkan tanpa air dan 0.31A ketika di dalam lumpur. Dari hasil pengukuran tersebut dapat disimpulkan bahwa pompa air Yamano WP 105 mengalami masalah ketika arus lebih besar $0.3 \mathrm{~A}$.

\section{Pengujian Sensor Level Air}

Sensor level air yang digunakan selanjutnya diuji kepekaannya dengan memasukkan air kedalam dan kemudian diangkat dari air. LCD 16 × 2 digunakan sebagai indikator pembanding. Delay waktu juga diuji untuk mengetahui berapa lama respon sensor. Respon sensor yang dimaksud adalah kecepatan pembacaan sensor ketika mengenai air atau keluar dari air dimana data pembacaan ditampilkan pada LCD $16 \times 2$. Tabel 2 memperlihatkan data pengujian sensor level air.

Tabel 2. Pengujian Respon Sensor Level Air

\begin{tabular}{|c|l|l|l|}
\hline No & Sensor air & Indikator LCD & Delay \\
\hline $\mathbf{1}$ & Masuk ke air & Aman & 1 detik \\
\hline $\mathbf{2}$ & keluar dari air & Bahaya & 4 detik \\
\hline
\end{tabular}

Data dari hasil pengujian sensor menunjukkan ketika sensor keluar dari air memiliki respon lebih lama. respon lebih lama disebabkan masih ada air yang menempel di permukaan sensor.

\section{Pengujian SMS}

Pengujian SMS dilakukan untuk mengetahui SMS yang dikirim dapat atau tidak mengendalikan pompa air. Pengujian juga bertujuan untuk mengetahui apakah SMS yang diterima sesuai dengan kondisi pompa air. Tabel 3 menunjukkan pengujian kendali pompa air dengan SMS.
Tabel 3. Kendali Pompa Air dengan SMS

\begin{tabular}{|c|c|c|c|c|c|c|}
\hline No. & $\begin{array}{c}\text { Teks } \\
\text { SMS } \\
\text { Dikirim }\end{array}$ & $\begin{array}{c}\text { Pompa } \\
\text { Air }\end{array}$ & $\begin{array}{c}\text { Delay } \\
\text { SMS } \\
\text { dikirim }\end{array}$ & $\begin{array}{c}\text { Teks SMS } \\
\text { diterima }\end{array}$ & $\begin{array}{c}\text { Delay SMS } \\
\text { diterima }\end{array}$ & $\begin{array}{c}\text { Total } \\
\text { Delay }\end{array}$ \\
\hline \hline $\mathbf{1}$ & Hidup & Menyala & 6 detik & $\begin{array}{c}\text { Pompa } \\
\text { Dihidupkan }\end{array}$ & 7 detik & $\begin{array}{c}13 \\
\text { detik }\end{array}$ \\
\hline $\mathbf{2}$ & Mati & Mati & 6 detik & $\begin{array}{c}\text { Pompa } \\
\text { Dimatikan }\end{array}$ & 7 detik & $\begin{array}{c}13 \\
\text { detik }\end{array}$ \\
\hline
\end{tabular}

Selanjutnya uji coba dilanjutkan dengan memonitoring pompa air, yaitu dengan cara mengirim SMS "Kondisi" ke alat. Setelah SMS terkirim maka alat membaca setiap sensor dan hasil dari pembacaan sensor dikirim ke ponsel pengguna berupa. Tabel 4 menunjukkan dari hasil pengujian monitoring pompa melalui SMS.

Tabel 4. Hasil Monitoring Pompa Air melalui SMS

\begin{tabular}{|c|c|c|c|c|}
\hline $\begin{array}{c}\text { Teks SMS } \\
\text { dikirim }\end{array}$ & $\begin{array}{c}\text { Kondisi } \\
\text { Pompa }\end{array}$ & Sensor air & $\begin{array}{c}\text { Teks SMS } \\
\text { Diterima }\end{array}$ & $\begin{array}{c}\text { Delay SMS } \\
\text { diterima }\end{array}$ \\
\hline Kondisi & Mati & Diatas Air & $\begin{array}{c}\text { Pompa Mati } \\
\text { Air Kosong }\end{array}$ & 7 detik \\
\hline Kondisi & Mati & Didalam Air & $\begin{array}{c}\text { Pompa Mati } \\
\text { Air Aman }\end{array}$ & 7 detik \\
\hline Kondisi & Menyala & Didalam Air & $\begin{array}{c}\text { Pompa } \\
\text { Hidup }\end{array}$ & 6 detik \\
\hline
\end{tabular}

Pengujian selanjutnya yaitu melihat apakah SMS dapat terkirim ke ponsel pengguna apabila pompa air mengalami masalah. Pompa air mengalami masalah yaitu ketika arus pompa air lebih besar $0.3 \mathrm{~A}$, dan ketika air dibawah batas minimum. Selain SMS terkirim ke ponsel pengguna, pompa air juga dimatikan jika pompa air mengalami masalah. Tabel 5 memperlihatkan pengujian SMS ketika pompa air mengalami masalah. 
Tabel 5. Pengujian SMS ketika Pompa Mengalami Masalah

\begin{tabular}{|c|c|c|c|c|c|}
\hline No. & Arus & Sensor Air & $\begin{array}{c}\text { Pompa } \\
\text { Air }\end{array}$ & $\begin{array}{c}\text { Indikator } \\
\text { SMS }\end{array}$ & $\begin{array}{c}\text { Delay } \\
\text { Pengiriman } \\
\text { SMS }\end{array}$ \\
\hline $\mathbf{1}$ & $0.22 \mathrm{~A}$ & Didal am air & menyala & - & - \\
\hline $\mathbf{2}$ & $0.22 \mathrm{~A}$ & Diatas air & mati & Terkirim & 8 detik \\
\hline $\mathbf{3}$ & $0.35 \mathrm{~A}$ & Didalam Air & mati & Terkirim & 8 detik \\
\hline $\mathbf{4}$ & $0.35 \mathrm{~A}$ & Diatas Air & mati & Terkirim & 8 detik \\
\hline
\end{tabular}

\section{KESIMPULAN}

Sistem kendali dan monitoring pompa air di daerah persawahan yang dirancang bekerja dengan baik sebagaimana yang diharapkan. Dimana pompa dapat dikendaliakan jarak jauh dengan SMS. Sensor arus ACS712 dapat membaca perubahan arus pada pompa air ketika arus lebih dari $0.3 \mathrm{~A}$ berarti pompa air bermasalah atau mengalami kerusakan sehingga menyebabkan boros tenaga listrik. Sensor level air juga mendeteksi kondisi air sehingga mengantisipasi pompa bekerja tanpa air dengan mematikan pompa ketika air melewati sensor level air. Ketika pompa air mati dan hidup SMS dapat terkirim ke ponsel pemilik dengan baik.

Sistem sudah berjalan baik namun masih membutuhkan penyempurnaan dengan penambahan beberapa komponen pendukung. Flow sensor diperlukan untuk mendeteksi kecepatan aliarn air. Kemudian penerapan komunikasi internet karena perkembangan zaman yang serba menggunakan internet dengan temuan baru yang dituangkan secara akurat dan mendalam.

\section{DAFTAR PUSTAKA}

[1] Anonim. Pengertian Arduino Uno. https://ilearning.me/sample-page-

162/arduino/pengertian-arduino-uno/. 04-06-2019. 21.20

[2] Dilcshon Kho. Pengertian Relay dan Fungsinya. https://teknikelektronika.com/pengertian-relay-fungsirelay/. 04-06-22.00

[3] Fatori, Muhamad Maftuh Fuad, Fiqqih Faizah, Devi Arisand. 2017. "Rancang Kontrol Dan Monitoring Sistem Proteksi Pompa Air Submersible Berbasis Arduino Nano". ISSN : 2548-8112

[4] Fitriandi, Afriza, Endah Komalasari, Herri Gusmedi. 2016. Rancang Bangun Alat Monitoring Arus dan Tegangan Berbasis Mikrokontroler dengan SMS Gateway. Electrician - Jurnal Rekayasa dan Teknologi Elektro Vol.10, No.2

[5] Muradi, Dany Ratminto. 2018. Rancang Bangun Sistem Pemantau Keamanan Terhadap Pencurian Pada Lumbung Padi Menggunakan Sms Gateway Berbasis Atmega 32. Bachelors Degree (S1) thesis, .University of Muhammadiyah Malang.

[6] Teori Elektronika. 2018. LCD (Liquid Cristal Display). https://elektronika-dasar.web.id /. 04-06-2019. 22:30 